\title{
Teoria da Justa Causa no Direito Penal e no Processo Penal
}

\author{
Plinia de Oliveina Cossêa \\ Professor de Direito Processual Penal nas Faculdades de Direito da UFRGS e \\ da PUCRGS - Conferência proferida em 25.09.97, na Escola de \\ Preparação e Aperfeiçoamento de Magistrados da Bahia.
}

-

Justa Causa no Direito Penal e no

Processo Penal é o tema que nos coube examinar nesta Jornada para Juízes Criminais, - promovida pelo Instituto Max Planck, da Alemanha, aqui representado pelo conceituado Jurista KURT MADLENER, e pela Escola de Preparação e Aperfeiçoamento de Magistrados da Bahia, dirigida pelo consagrado Professor e eminente Magistrado, Desembargador GERSON PEREIRA DOS SANTOS.

$E$, ao enfrentar esta difícil abordagem, pedimos venia aos ilustrados Juristas nacionais e estrangeiros, e, particularmente, aos Magistrados deste Estado da Federação, para apresentar, inicialmente, um quadro geral do instituto jurídico da justa causa no âmbito do processo penal brasileiro.

\section{Dos Diversos \\ Posicionamentos}

A expressão justa causa assume diferentes significados, que podem ser agru- pados, no mínimo, em oito correntes de pensamento, a saber:

A primeira posição, vincula a justa causa ao conceito de prisão;

A segunda, a utiliza para fundamentar a concessão de habeas corpus quando o fato imputado não constituir infração penal;

A terceira, fixa a falta de justa causa como figura equivalente às hipóteses do artigo 43 do Código de Processo Penal;

A quarta, a situa como elemento identificador nos casos de coação ou constrangimento ilegal;

A quinta, vê a presença da justa causa tão somente na descrição de um fato delituoso na peça acusatória;

A sexta posição, embora restrita à ação penal privada, se apoia apenas em indícios ou suspeitas fundadas;

A sétima, elimina a expressão do sistema processual penal brasileiro;

A oitava posição, coloca a justa causa como uma das condições da ação penal. 


\section{Crítica às Diferentes Posições}

Com efeito, torna-se imprescindível fazer, ainda que rapidamente, uma análise crítica desses posicionamentos para melhor atingir a natureza jurídica do instituto, ou, pelo menos, para saber onde está situada a justa causa dentro do quadro proposto.

Assim, quanto à primeira posição isto é, a que liga a justa causa ao conceito de prisão - cabe destacar que ela remonta ao Código de Processo Criminal de 1832 , ao consagrar este preceito no artigo 353 :

"A prisão julgar-se-á ilegal:

1) quando não houver justa causa

No mesmo sentido, o Decreto $\mathrm{n}^{\mathrm{O}}$ 3.084 , de 05 de novembro de 1898, que consolidou as Leis da Justiça Federal, prescrevia no seu artigo 360 , que a prisão era ilegal quando não houvesse justa causa para ela.

Fiel a esta orientação, e até refletin do a legislação ordinária então existente, $o$ Supremo Tribunal Federal, no seu Regimen to Interno de 24 de maio de 1909, estabelecia no artigo 112 que:

"A prisão, ou constrangimento, se julgará ilegal:

1) quando não tiver justa causa".

Os Códigos de Processo Penal dos Estados - que resultaram da consagração do princípio da descentralização processual na Constituição de 1891, e que perduraram até 1941, - por sua vez, com rara exceções, continham disposições idênticas, considerando a justa causa como motivo determinante da legalidade da prisão, se presente, ou da ilegalidade, quando ausente.

No entanto, este entendimento merece ser criticado, uma vez que não se concebe hoje, como não se concebia ontem, condicionar-se a idéia de justa causa ao conceito de legalidade ou ilegalidade da prisão. E a razão é simples: a prisão pode ser legal, como ocorria com as prisões administrativa, disciplinar e. para averiguação, e inexistir legitimidade para qualquer uma delas, como já tivemos oportunidade de demonstrar em estudo intitulado Autoridade Competente para Ordenar a Prisão no Direito Brasileiro, Editora da Ufrgs, 1981.

Por conseguinte, não mais cabe falar em legalidade ou ilegalidade da prisão, mas na sua legitimidade ou ilegitimidade.

No que diz respeito à segunda posição, aquela que utiliza a justa causa para fundamentar a concessão de habeas corpus quando o fato imputado não constituir crime, encontrou embasamento legal, inicialmente em três Códigos Estaduais: o do Rio Grande do Sul, o do então Distrito Federal e o de Santa Catarina. Estes três diplomas, apesar de manterem a linha tradicional antes referida, trouxeram algumas inovações que caracterizaram esta corrente de pensamento.

O primeiro, o do Rio Grande do Sul, considerava nos artigos 254 e 255 da Lei Estadual $\mathrm{n}$ - 24, de 15 de agosto de 1898 (com as modificações introduzịdas pela Lei no 141, de 23 de julho de 1912) a imputação de "fato não criminoso" como cons- trangimento ilegal ou abusivo para se conceder habeas corpus por falta de justa cau sa.

O segundo, o do Distrito Federal, estatuía no Decreto nำ 8.259, de 29 de se tembro de 1910, assinado pelo Presidente NILO PEÇANHA, este princípio no artigo 382 :

"A prisão ou constrangimento jul gar-se-á ilegal em qualquer dos seguintes ca sos:

$1^{\circ}$ - quando não houver justa causa ou o fato não constituir crime".

E o terceiro, o de Santa Catarina, promulgado pela Lei Estadual no 1.640, de 03 de novembro de 1928, depois de valorizar a justa causa no artigo 2.564 , determi nava no artigo 2.565

"Ainda depois da pronúncia ou da condenação, o habeas corpus pode ser concedido nos seguintes casos:

II - Quando o fato imputado não constituir crime".

Este posicionamento encontrou res sonância não só na Jurisprudência dos nos sos Tribunais, mas também na palavra de ilustrados Mestres do Direito, como FLORÊNCIO CARLOS DE ABREU E SILVA, que afirmava não existir justa causa "quando o fato de que o paciente é acu sado não constituir crime ou contravenção penal" (in Comentários ao Código de Processo Penal, Vol. V, p. 565, Forense, 1945).

A crítica que pesa sobre esta posição pode restringir-se no seguinte: Se o fato narrado na peça inicial não constituir crime, o juiz deve, de imediato, aplicar o preceito contido no artigo 43, inciso I, do Código de Processo Penal, que diz:

"A denúncia ou queixa será rejeita-

I- o fato narrado evidentemente nã constituir crime".

Logo, se existe regra expressa regulando a matéria, não deve haver lugar para metáfora jurídica ou qualquer outro simbo lismo, ainda insuficientemente definido.

Ademais, não existe conveniência alguma em cognominar de justa causa te mas com denominações próprias e já devidamente assentados na literatura jurídica.

A terceira posição é mais recente e surgiu com o advento do atual Código de Processo Penal, de 1941. Este Código resultou do retorno do princípio da unidade processual, que passou a vigorar no nosso sistema constitucional a partir da Constituição de 1934, perdurando até hoje, o qual aboliu, conseqüentemente, o regime dos Códigos Estaduais e instituiu um único Código Nacional, promulgado pelo Decreto-Lei $\mathrm{n}$-3.689/41.

A citada posição define a falta de jus ta causa como elemento equivalente às hipóteses previstas no artigo 43 deste Código Nacional, neste termos:

"A denúncia ou queixa será rejeitada quando: I - o fato narrado evidentemente não constituir crime; II - já estiver extinta a punibilidade, pela prescrição ou outra causa; III - for manifesta a ilegalidade da parte ou faltar condição exigida por lei para o exercício da ação penal".

Regra semelhante consta do artigo 78 do Código de Processo Penal Militar (De- 
creto-Lei $\mathrm{n}^{\mathrm{o}} 1.002$, de 21 de outubro de 1969 ).

Como se verifica pela leitura do mencionado artigo 43 e seus incisos, estes contém casos de diferentes naturezas, tais como: elementos formais da peça acusatória, extinção de punibilidade e condições genéricas da ação penal.

Tal artigo compreende, assistematicamente, uma miscelânea de diversos institutos. Dessa forma, é inconcebível pretender-se que a expressão justa causa compreenda, traduza ou reflita por ela mesma todos esses temas e situações heterogêneas.

Entre os autores modernos que, data maxima venia, incorrem nesta injustificável equiparação estão DARCI ARRUDA MIRANDA (in Comentários à Lei de Imprensa, Vol. II, p. 744, Ed. Revista dos Tribunais, 1969), FREITAS NOBRE (in A Le de Imprensa, p. 206, Saraiva, 1968) e JOSÉ RAIMUNDO GOMES DA CRUZ (artigo publicado na Revista dos Tribunais Vol.423, p. 303 e segs.)

A quarta posição situa a falta de jus ta causa como elemento identificador do demais casos de coação ou de constrangimento ilegal, enumerados no artigo 648 do Código de Processo Penal, que dispõe:

"A coação considerar-se-á ilegal: I quando não houver justa causa; II. - quando alguém estiver preso por mais tempo do que determina a lei; III - quando quem ordenar a coação não tiver competência para fazê-lo; IV - quando houver cessado o motivo que autorizou a coação; V - quando não for alguém admitido a prestar fiança, nos casos em que a lei a autoriza; VI - quando o processo for manifestamente nulo; VII - quando extinta a punibilidade".

Idêntica regra prevê o artigo 467 do Código de Processo Penal Militar.

Esta posição foí defendida, em parte, pelo Professor JOSÉ FREDERICO MARQUES, para quem, nos casos referidos, a justa causa funcionaria "como norma genérica de encerramento" do processo (in Elementos de Direito Processual Penal, Vol. IV, p. 398, Forense, 1965).

Com efeito, ao analisarmos as hipóteses do artigo 648 do Código de Processo Penal, - constatamos a presença de questões relativas à competência, aos pressupostos processuais, à prestação de fiança, a nulidades processuais, excesso de prazo na prisão, entre outras. Por conseguinte, aqui também é inconcebível a utilização da justa causa como expressão "universal" para identificar os mais variados institutos e as mais diversas situações jurídicas. A identificação pretendida nesta posição, assim como a equivalência sugerida na anterior, não passam de meras opiniōes destituídas de qualquer valor científico.

A quinta posição é a que visualiza a presença da justa causa com a simples descrição de fato delituoso na denúncia ou na queixa. Este entendimento é retirado da jurisprudência, donde se destacam, exemplificativamente, estes dois julgados:

SUPERIOR TRIBUNAL MILI-

TAR, no Habeas Corpus no 27.849 :

"Desde que o fato narrado na denúncia constitui, em tese, crime militar, existe justa causa para o processo, que não pode- rá ser trancado por meio de habeas corpus" (ROMEIRO NETO, in O Direito Penal Militar Nos Casos Concretos, pág. 76, ed. J. Konfino, 1966)

TRIBUNAL DE JUSTIÇA DO RIO GRANDE DO SUL, no Habeas Corpus $\mathrm{n}^{\mathrm{O}} 15.357$ :

"Estando descrito, na denúncia, fato criminoso, em tese, há justa causa para a ação penal" (in RJ/TJRGS, 50/17).

Esta posição confunde justa causa com a descrição na inicial de um fato que, em tese, constitui crime. Contenta-se, apenas, com a versão, esquecendo da comprovação do fato, pois justa causa, como se verá adiante, não está no que se transcreve numa folha de papel (denúncia), mas na prova do que dá origem à denúncia (o fato).

A sexta posição - restringe o embasamento da queixa-crime a indícios ou suspeitas - e é representada por este entendimento do SUPREMO TRIBUNAL FEDERAL:

"Para que tenha viabilidade a proposta acusatória, não basta que a queixa crime contenha a descrição completa dos fatos criminosos e da conduta do acusado (...) é imprescindivel que ela se apoie em indícios ou suspeitas fundadas, sob pena de deixar-se ao talante de arbitrárias alegações a movimentação do aparelho repressivo penal e o acarretamento de constrangimento à pessoa acusada, sem justa causa para tan to" (Inq. 112, Rel. Min. RAFAEL MAYER, apud Rev. STJ, Vol. 36, págs. 23 e 24).

Com o devido respeito, nos parece frágil e perigoso o entendimento que considera suficientes apenas indícios ou suspeitas, tanto para o fato quanto para a autoria, indistintamente, sem atentar para as parti cularidades daquele e desta. Se indícios ou suspeitas bastam para a autoria, o mesmo critério não pode valer para o fato, o qua requer prova e não suspeita da sua existên cia.

Assim, é por demais temerário admitir-se o propositura de ação penal contra alguém com base tão somente em indícios ou suspeitas da existência de fato delituoso. Isto afronta não só ao princípio processua do onus probandi (art. 156 CPP), mas tam bém ao preceito constitucional da presun ção de inocência (art. 5ㅇ, LVII, CF).

A sétima posição é a que elimina expressão justa causa, tendo como justificativa a heterogeneidade de tratamento a dificuldade de conciliar divergências de significações. Este é o posicionamento do já citado JOSÉ RAIMUNDO GOMES DA CRUZ, em artigo publicado na Revist "Justitia" (Vol. 58, p.70), onde sugere expressamente a sua supressão dos textos nos quais figura na nossa legislação processual penal.

A crítica que se pode fazer a esta posição é a de que ela peca por omissão esquecendo de bem conceituar um instituto que há mais de cento e sessenta anos fi gura na legislação brasileira. Esta omissão por parte dos nossos doutrinadores é, na verdade, injustificável.

A oitava e última posição, como já se viu, é a que coloca a justa causa com uma das condições da ação penal. Esta cor rente doutrinária foi acolhida pelo nosso direito positivo com a edição da Lei $n$ 5.250 , de 09 de fevereiro de 1967 , que re gula a liberdade de manifestação do pen 
samento. O parágrafo 1을 do artigo 44 dessa lei não deixa a menor dúvida quanto à de. finitiva incorporação do instituto da justa causa como uma condição da ação penal. Diz o aludido preceito: "A denúncia ou queixa será rejeitada quando não houver justa causa para a ação penal".

\section{Conceito de Justa Causa no Processo Penal}

Posicionada a justa causa, como condição essencial para o exercício da ação penal, cabe, agora, perquirir a respeito da noção conceitual deste importantíssimo instituto jurídico.

Com efeito, o direito de petição é uma garantia tradicionalmente assegurada no constitucionalismo brasileiro e, particularmente, no capítulo dos direitos indivi duais da atual Constituição da República (art. 5o, XXXIV, "a"). Do gênero, direito constitucional de petição, decorre a espécie, isto é, o direito à Provocação Jurisdicional (P.O.C. ed. Ufrgs, 1978), donde resulta, especificamente, o direito de ação penal.

Representa o direito de petição a forma mais ampla e democrática dos cidadãos, em geral; reivindicarem providências do Estado-Administração; ao passo que o direito de ação penal é o modo pelo qual se pode bater à porta do Estado-Jurisdição em busca de definição jurídica a respeito de uma hipótese delitiva atribuída a alguém e pretendendo o seu enquadramento em determinado tipo penal.

Derivam, daí, duas situações distintas: no direito de petição o postulante pede um benefício para si ou para outrem; e no direito de ação penal o acusador imputa um fato delituoso ao acusado, requerendo um malefício para ele, ou seja, uma sanção penal.

Constata-se, pois, um conflito de in teresses entre o jus persequendi e o jus libertatis, cujo desate jurisdicional se dará através do devido processo e com estas diferentes facetas dos sujeitos processuais: a tese, a antítese e a síntese.

Se, de um lado, o direito de petição é amplo e ilimitado, de outro, o direito de ação penal é restrito e condicionado. Por isso - e a fim de afastar abuso de direito e prevenir lesão à liberdade individual - só se admite desencadear a ação penal se se fizerem presentes as condições da ação, divididas, didaticamente, em condições gerais, especiais e formais (P.O.C., in Legitimidade da Prisão no Direito Brasileiro, pág. 96, Sagra, 1991).

Dentre as condições gerais destacase a justa causa, como base fundamental do legítimo exercício desse direito, cujo conceito é assim proposto à consideração dos ilustres participantes deste Evento:

Justa Causa, como condição primeira para o exercício da ação penal, consiste na prova induvidosa da existência de uma hipótese delitiva e, pelo menos, em indícios idôneos de sua autoria (P.O.C., in RSP 111/ 59, Funcep).

O citado conceito de justa causa foi recomendado pela Associação Brasileira dos Advogados Criminalistas e referendado pela Associação Americana de Juristas (cf. "Carta de Gramado" de 02.07.95, in Jornal do Criminalista/ ACRIERGS, $\mathrm{n}^{\circ}$ 01, pág. 08).
Coincidentemente, o Anteprojeto de Código de Processo Penal, depois de analisado, minuciosamente, por todas as instituições jurídicas do País, optou, amadurecidamente, por um preceito que se identifica com esta posição doutrinária que temos defendido por mais de cinco lustros (art. 9, do Projeto no 633/75)

"Não será admitida ação penal pública ou privada sem a prova da existência do crime e indícios suficientes de sua autoria"

A ausência deste requisito básico tem levado os nossos Tribunais a conceder ordem de habeas corpus por falta de justa causa, trancando a ação penal que for exercida abusivamente ou que resultar de pura criação mental do acusador (RF 150/ 393; RTJ 90/1014; RJ/TJRGS 98/32).

Assim, promover a instauração de processo penal sem prova pré-constituída da existência do fato e indícios da autoria, é promover denúncia vazia, destituída de qualquer suporte fático (CPP, arts. 12, 27, $39, \S 5^{\circ}$ ), afrontando ao princípio da presunção de inocência não só no âmbito constitucional brasileiro (CF, art. 50, LVII), mas também no plano internacional (DUDH, art. 11).

Eis porque convém sublinhar alguns esforços legislativos direcionados ao conceito de justa causa, aqui defendido:

* Em 1963, o Prof. HÉlIO BASTOS TORNAGHI registrou no seu Anteprojeto de Código este preceito no artigo 23:

"A denúncia terá de ser apresentada sempre que houver:

a) prova de fato que, em tese, constitua crime b) prova que abone a suspeita de autoria" (g. n.)

* O Código de Processo Penal Mili$\operatorname{tar}$ (Decreto-Lei $\mathrm{n}^{\mathbf{0}}$ 1.002/69), inspirado no Projeto TORNAGHI, instituiu esta regra no seu artigo 30, estabelecendo, então, os limites legais da obrigatoriedade de denunciar:

"A denúncia deve ser apresentada sempre que houver:

a) prova de fato que, em tese, constitua crime;

b) indícios de autoria" (g. n.).

* E, na Câmara dos Deputados, durante a tramitação do Projeto no 633/75, que instituia o Código de Processo Penal (o qual chegou a ser aprovado por unanimidade, mas quando tramitava no Senado Federal sob o $\mathrm{n}^{\mathrm{0}}$ 05/78, foi, lamentavelmente, retirado pelo Poder Executivo, através de Mensagem Presidencial de 30.08.78), foram apresentadas duas importantes emendas:

Emenda no 8, de autoria do Deputado JOSÉ BONIFÁCIO NETO, equiparando a expressão justa causa a estes elementos:

"prova da existência do crime e indícios veementes da autoria" (g. n.);

Emenda no 9, apresentada pelo Deputado LIDOVINO FANTON:

"Dê-se ao parágrafo único do art. 8a a seguinte redação: Para que haja justa causa é necessário:

a) prova de fato que, em tese, constitua crime;

b) prova que abone fundada suspeita de autoria" (g. n.). 
* Destas emendas, cabe destacar este tópico do Parecer proferido pelo Deputado SANTOS FILHO, Sub-Relator da Comis são Especial do Projeto:

"A linguagem empregada pelo Projeto nos parece incensurável, pois, em não havendo prova da existência do crime indícios de autoria, não haverá justa causa para a ação penal" (g. n.).

Saber, com clareza e precisão, em que consiste a imputação que lhe é feita, é, hoje, um direito indiscutido e indiscutível de todo e qualquer cidadão (RTJ 33/430), não apenas para poder bem se defender, mas para possibilitar a justa prestação jurisdicional da res judicanda no processo penal.

Por estas considerações, a nossa sistemática jurídica nos autoriza a dizer que o conceito de justa causa se assenta em dois sólidos pilares:

a) na prova da existência de uma hipótese delitiva;

b) na prova ou, pelo menos, em in dícios idôneos de sua autoria.

\section{Crítica ao Sistema Brasileiro}

Por outro lado, além do desleixo dou trinário na elucidação conceitual da justa causa, - o próprio direito positivo brasileiro tem incentivado esta instabilidade proces sual, como se verifica de diversos dispositivos legais. Senão vejamos exemplificativamente:

\section{Código de Processo Penal}

A) “Art. 386 - O juiz absolverá o réu, mencionando a causa na parte dispositiva, desde que reconheça: (...) II não haver prova da existência do fato" (g. n.). Idêntico preceito encontramos no artigo 439, letra "a" do Código de Processo Penal Militar.

É inconcebível que tal fundamento figure como regra para toda sentença final, admitindo-se, pois, que todo e qualquer processo possa ser instaurado sem a prova da existência do fato. Inexistindo, previamente, esta prova, o Magistrado não deverá sequer receber a peça inicial por falta de justa causa, ou melhor, por carência de ação.

No entanto, caso tenha recebido desapercebidamente, a peça acusatória com esta gravíssima falha, o titular do poder jurisdicional há de ter a dignidade de reconsiderar a qualquer momento aquele despacho para o fim de rejeitá-la, ou, então, ter a coragem funcional de conceder habeas corpus de ofício com o mesmo objetivo, respeitada, apenas, a hierarquia judiciária.

Desta forma, quando se fizerem pre sentes os requisitos necessários à sua instauração, o processo será o meio legítimo para a aplicação do Direito e a realização da Justiça, assim como o instrumento adequado e seguro para garantir ao acusado a observância do princípio da ampla defesa e, até, para demonstrar a sua inocência, embora este status deva perdurar até o trânsito em julgamento da sentença penal condenatória ( art. 5은 LVII, CF).

B) “Art. 513 - Nos crimes de responsabilidade dos funcionários públicos, cujo processo e julgamento competirão aos juízes de direito, a queixa ou a denúncia será instruída com documentos ou justificação que façam presumir a existência do delito ou com declaração fundamentada da impossibilidade de apresentação de qualquer dessas provas" (g. n.).

O texto ora transcrito não resiste à crítica mais elementar por permitir a propositura da ação penal, insuficientemente instruída com documentos que levam apenas à presunção (e não à prova da certeza) da existência do delito ou (o que é mais reprovável) com declaração da im possibilidade de apresentação de qualquer dessas provas, isto é, tanto da que se refere à existência do fato quanto à dos indícios da autoria.

Admitir este absurdo é admitir denúncias vazias e processos fantasmas, fabricados para satisfazer interesses escusos e inescrupulosos, dando vazão à chicana e a constrangimentos ilegais até o pronunciamento jurisdicional, que, fatalmente, deverá levar à absolvição do acusado por não haver prova da existência do fato e por não existir prova ou indícios da autoria.

Este procedimento especial não só ignora as conquistas dos direitos individuais e das garantias processuais, como também estabelece forma retrógrada, anticientífica e altamente perigosa a qualquer servidor público federal, estadual ou municipal, que venha a ser acusado da prática de algum delito funcional (arts. 312/ 327, CP)

\section{Lei $n^{\circ} 8069 / 90$ (Estatuto da Criança e do Adolescente). Art. 182, $\$$ 20: "A representação independe de prova pré-constituída da autoria e materalidade"}

A exemplo dos dois anteriores, este preceito é deplorável, pois admite que al- guém possa ser processado sem qualquer prova da existência do fato e indícios da autoria.

A supra citada representação está equiparada à denúncia, de cujo processo poderá culminar a aplicação das sanções penais enumeradas no artigo 112 do ECA, além da pesada pena de sujeitar o adoles. cente a um processo fictício, que, nos termos desta lei, não precisa assentar-se na prova da materialidade e da autoria, mas em simples suposição, suspeição, presunção - e por que não dizer - na imaginação e na subjetividade de um acusador...

A mencionada regra - que coloca todo adolescente sob suspeita e, potencialmente, no banco dos réus - foi aprovada, desavisadamente, pelas duas Casas do Congresso Nacional e promulgada, desassessoradamente, pelo Presidente da República, retroagindo ao tempo do inquisitorialismo, pois foi esquecido por todos que o ônus da prova é de quem acusa (CPP, art. 156). Ademais, em se tratando de justa causa, como condição primeira para o exercício da ação penal, a análise da prova da materialidade e indícios da autoria deve ser feita previamente, por ocasião da instauração do processo e não ao seu final (art. 189, II), o que é mais uma impropriedade desta lei.

Mas, se houve cochilo do Legislativo, que elaborou esta norma, e do Executivo, que a sancionou, - o Judiciário, certamente, estará atento a esta incongruência para o fim de conceder habeas corpus voluntário ou de ofício, trancando eventual atuação acusatória, que se pretender, absurdamente, processar um adolescente 
sem qualquer elemento probatório da materialidade e da autoria. A propósito, o Desembargador SÉRGIO GISCHKOW PEREIRA, em recente julgamento (TJ/RGS PROC. № 597009232), proferiu brilhante voto, do qual se transcreve este trecho: "Não entendo que a regra que faz independer a representação de prova préconstituída da autoria e materialidade esteja em harmonia com essa absoluta priorização do respeito à liberdade, à dignidade do adolescente; e também não entendo que não esteja ocorrendo uma verdadeira discriminação aos menores (...), porque sabemos perfeitamente que da aplicação do Estatuto pode resultar, como providência, a internação do menor. Portanto, está em jogo o que diz com a liberdade. (...) Considero também que não atende ao requisito do respeito à dignidade do menor estarmos admitindo que ele seja submetido a um procedimento, quando não há nenhuma prova sequer da materialidade e também não há nenhum indício de autoria. (...) Acredito, portanto, que de fato exorbitou, neste ponto, o Estatuto da Criança e do Adolescente e que a norma fere a Constituição Federal".

Organizado por OLÍRIO CAVALIERI, a Editora Forense publicou em 1995 o livro intitulado "Falhas do Estatuto da Criança e do Adolescente", donde se retiram estes abalisados depoimentos:

SAMUEL ALVES DE MELLO JÚNIOR: "O parágrafo 2ㅇ do art. 182 abre a possibilidade de o Ministério Público fazer uma "denúncia" sem prova pré-constituída de autoria e da materialidade da infração, enquanto se fala em dar efetivas garantias constitucionais ao menor como cidadão. Onde, está, a tão apregoada garantia?";

LIBORNE SIQUEIRA: "O art. 182, parágrafo $2^{\circ}$ do Estatuto diz que a representação, entenda-se como denúncia, independe de prova pré-constituída da autoria e da matérialidade. É norma fascista, arbitrária e hiperprocessual-penal, não aplicável nem mesmo para o adulto";

ROSÂNGELA ZAGAGLIA: O preceito "fere princípios de proteção integral, indo além do Código de Processo Penal".

No mesmo sentido é o entendimento da Professora TÂNIA DA SILVA PEREIRA (in Revista Literária de Direito, $\mathrm{n}^{\circ}$ 16, pág. 29)

Como se verifica, o mencionado preceito legal colide com a letra e com o espírito da nossa Carta Política, pois: a) Não se coaduna com o fato dos maiores de 18 anos disporem da garantia processual da justa causa, como condição sine qua non para o exercício da ação penal (podendo até ocorrer o seu trancamento, mediante a impetração de habeas corpus, cf. art. 648, I, CPP), e os menores terem de suportar um processo, cuja instauração carece de justa causa, havendo, pois, manifesta desigualdade em relação aos menores; b) Ter ciência dos termos da acusação e, sobretudo, conhecer as provas que a instruíram é imprescindível para poder exercer a amplitude do direito de defesa, (art. 5ㅇ, LV); c) A norma constitucional garante, com absoluta prioridade, o pleno e formal conhecimento do ato infracional, a igualdade na relação processual e a defesa técnica ao adolescente (art. 227, § 3ㅇ, IV); d) e esta lei, ao estabelecer que a instauração de processo contra o adolescente independe de prova da autoria e materialidade (art. $182, \S 2^{\circ}$ ), nega os compromissos instituí-dos pela nossa Lei Maior.

Por estas razões, o preceito do parágrafo $2^{\circ}$ do artigo 182 do ECA é ilegítimo e inconstitucional.

Por conseguinte - relembrando a memorável lição de RADBRUCH, para quem "há leis que não são direitos e $\mathrm{Di}$ reitos que estão acima das leis" - é oportuno invocar a incidência do sábio brocardo latino "Pro Jure Quamvis Contra Legem" e dizer que, nestes casos, estamos Com o Direito Ainda que Contra a Lei.

\section{Direito Comparado:}

\section{Hispano-Luso-Brasileiro}

Face a estas breves considerações em torno do nosso direito positivo, cabe registrar que à semelhança do que ocorre no Brasil, os demais países deste continente sofrem do mesmo mal: carecem da garantia processual da justa causa e de uma adequada conceituação do instituto.

Tal situação advém, primordialmente, da implantação do sistema inquisitório (instituído por Inocêncio III, no Concílio de Latrão, em 1215, e "codificado" em 1.484 por Inocêncio VIII), alastrando-se por todo o continente europeu, inclusive pelos tribunais civis, particularmente em Portugal e na Espanha, onde se adotou as práticas desumanas dessa filosofia, em que os acusados só tinham o direito de não ter direito algum.

Foram estes dois povos que transplantaram aquele regime para o continente latino-americano, regulando nossas relações jurídicas durante séculos e deixando a marca decisiva da influência do procedimento inquisitorial (J.F. MARQUES, in Elementos de Direito Processual Penal, Vol. I, pág. 89 , Forense, $2^{\underline{a}}$ edição)

A propósito desta influência, escreve o nosso JOÃO MENDES DE ALMEIDA JÚNIOR:

"Se no direito e no processo civil, prevaleceu o Direito Romano, o mesmo não aconteceu no processo criminal, onde as formas do Direito Canônico tiveram a mais decisiva preponderância, quer quanto ao processo escrito, quer quanto ao sistema inquisitório" (in O Processo Criminal Brasileiro, Vol. $1^{\circ}$, pág. 102, $3^{a}$ edição, Livraria Francisco Alves, 1920).

Como resultado, não só tivemos Códigos que já nasceram ultrapassados no tempo e no espaço, mas que ainda perduram por mais de um século (Código de Procedimentos em Matéria Criminal da Argentina, de 1888; Código de Procedimentos Penais do Paraguai, de 1890; e Código de Processo Criminal do Chile, de 1906), ignorando a evolução do direito processual penal e os avanços dos Direitos Humanos, especialmente da quase cinqüentenária Declaração Universal dos Direitos do Homém, cuja sessão histórica da ONU, em 10 de dezembro de 1948 , foi presidida pelo brasileiro OSWALDO ARANHA.

E os citados povos, cujas legislações nos influenciaram decisivamente, ainda não se libertaram, de todo, do sistema inquisitório. A ESPANHA, com a Ley de Enjuiciamento Criminal de 1882 , continua determinando que os agentes do $\mathrm{Mi}$ nistério Fiscal devem promover "todas las 
acciones penales que consideren procedentes" (art. 105, LECRIM), sem estabelecer, contudo, os critérios objetivos desse entendimento e omitindo-se quanto à prova do fato e indícios da autoria; e PORTU. GAL - mesmo tendo substituído o Código de Processo Penal de 1929 (Decreto no 16.489, de 15.02.29) pelo de 1987 (Decreto-Lei $\mathrm{n}^{\mathrm{o}} 78$, de 17.02.87) - ainda permite que alguém possa ser processado apenas por indícios, carecendo, pois, de justa causa:

$$
\text { Art. } 283 .
$$

1. Se durante o inquérito tiverem sido recolhidos indícios suficientes de se ter verificado crime e de quem foi o seu agente, o Ministério Público deduz acusação contra aquele.

2. Consideram-se suficientes os indícios sempre que deles resultar uma possibilidade razoável de ao arguído vir a ser aplicada, por força deles, em julgamento, uma pena ou uma medida de segurança.

Com se vê, a vetusta legislação espanhola é omissa, totalmente, a respeito; e a portuguesa é, no mínimo, equívoca; vigorando, em ambas, a interpretação eminentemente subjetiva do Ministério Público, que pode denunciar sem qualquer critério objetivo.

Como já foi acentuado, os indícios idôneos ou suficientes - estão para a autoria e não para o fato, pois em relação a este é necessário prova e não indício. Neste ponto o atual Código Lusitano regrediu para bem antes do antigo Código de 1929 , pois o artigo 345 do diploma revogado estatuía preceito mais consentâneo:

"Se não houver prova bastante dos elementos da infração ou de quem foram os seus agentes, aguardará o processo a produção de melhor prova..." (g. n.).

Os indícios "suficientes" do atual sistema português, assim como os "procedentes" do espanhol, resultam da convicção íntima do acusador e não de prova objetiva da materialidade. São preceitos que valorizam o arbítrio de quem acusa, carecendo de elementos concretos e objetivos.

Aqui no Brasil - uma ação penal promovida com base no artigo $283, \mathrm{n}$ 을 CPPP, ou no artigo 105 da LECRIM - certamente seria trancada e extinto o processo pela concessão de habeas corpus por falta de justa causa, nos termos do artigo 648, inciso I, do nosso Código de Processo Penal.

Com efeito, o princípio da presunção de inocência - previsto tanto na Cons tituição Portuguesa (art. 32, no 2), quanto na Espanhola (art. 24, no 2) e na Brasileira (art. 5으. LVII) - só pode ser quebrado em duas únicas circunstâncias:

a) materialmente, com o trânsito em julgado da sentença penal condenatória;

b) formalmente (ou processualmente), com a presença de justa causa para o exercício da ação penal.

No direito brasileiro, estando preso $\mathrm{o}$ indiciado, o inquérito policial deve ser concluído em dez (art. 10, CPP) ou em quinze dias (art. 66, Lei $\mathrm{n}^{\mathrm{o}}$ 5.010/66) e a inobservância deste prazo legitima a concessão de habeas corpus por excesso de prazo na formação da culpa (art. 648, II, $\mathrm{CPP}$ ), cuja contagem deve ser feita isoladamente (RTJ 58/388). Em Portugal, é o Ministério Público que realiza o inquérito (art. 263 CPPP). E, estando o arguído pre. so ou em regime de prisão domiciliar (art. 276, CPPP), também cabe habeas corpus (art. 222, no 2, letra "c", CPPP) se houver excesso do longo prazo legal, que, no caso, é de seis meses. Convenhamos, é muito tempo para que alguém, presumido inocente pela Constituição, permança preso, enquan to são procurados apenas indícios suficientes, a juízo exclusivo do Ministério Público.

A propósito, o Centro de Estudos Judiciários de Portugal promoveu um Ciclo de Conferências sobre o Novo Código de Processo Penal, do que resultou a publicação de um livro contendo a Primeira Fase das Jornadas de Direito Processual Penal. Dentre os inúmeros trabalhos, é oportuno destacar esta lição do Doutor JOSÉ SOUTO DE MOURA

“O Código não parece ser muito exigente para que os indícios se reputem 'suficientes'. No artigo 283, $n^{-} 2$, do Novo Código de Processo Penal, fala-se não em 'forte possibilidade' ou 'possiblidade séria' de condenação. Bas ta uma possibilidade 'razoável', a juizo do Ministério Público". (Ed.Livraria Almedina, Coimbra, 1989, ob. cit., pág. 115)

Concluindo esta primeira parte, Inobstante o aparecimento do sistema acusatório, valorizado pela Ordenação Francesa de 1539 , bem como sua lenta, mas constante difusão; embora tenha surgido o sistema misto e com ele o Code d'Instrucion Criminelle de 1808, por influência da Declaração de Direitos de 1789; mesmo assim o sistema inquisitório sempre contou com o apoio de aliados inseparáveis, fortes e poderosos: os governos despóticos ou ditatoriais, que de tempos em tempos aparecem no curso da história para infelicitar a humanidade.

É por isso que, ainda hoje, encontramos nas diferentes legislações preceitos inspirados no inquisitorialismo, como resultado da pressão desta espécie de governantes, que, da mesma forma que esmagam, que usam e que escravizam o seu povo, procuram esmagar, usar e escravizar o Direito, não só para manterem os seus privilégios, mas para se perpetuarem no poder.

E objetivando a sonhada, mas dificil, varredura do inquisitorialismo do nosso Continente, estamos apresentando uma dupla proposição: $1^{a}$ ) submeter o conceito de justa causa à judiciosa apreciação dos ilustrados juristas deste evento multinacional; e, $2^{2}$ ) sugerir a adoção do instituto da justa causa, ou do seu conteúdo, como garantia processual do cidadão, a figurar na ordem jurídica de cada País.

\section{vI. Justa Causa no \\ Direito Penal}

Cabe acrescentar, ainda, uma palavra sobre a justa causa no Direito Penal.

Bem ao contrário do que ocorre no Processo Penal, onde se constatou, no mínimo, oito posições diferentes a respeito do instituto da justa causa, - no Direito Penal as divergências são menores, podendo se afirmar, num primeiro momento, que o uso da expressão "justa causa" até tem significado convergente para um único direcionamento, ou seja, para excluir a incidência penal na conduta do agente.

Tanto é assim que os tipos penais não valorizam a expressão "justa causa", e sim 
a alocução "sem justa causa" para a configuração de hipóteses delitivas.

Vejamos, exemplificativamente, os preceitos dos artigos 135, 153, 154, 244, 246, 248 do Código Penal.

A mesma orientação é seguida pelo Código Penal Militar, nos artigos 201, 228 , 230 e 349.

Como se vê, o emprego da expressão "sem justa causa" integra o tipo na configuração da conduta delitiva, ao passo que, havendo justa causa, a ação ou omissão fica excluída do mundo jurídico penal.

Por conseguinte, - justa causa, con siderada isoladamente em cada caso, equivaleria a uma excludente a mais no elenco de especificações do artigo 23 do Código Penal; e, visualizada de forma genérica compreenderia todas as excludentes englobadamente, equiparando-se, assim, ao instituto da inexigibilidade de conduta diversa, concebida doutrinariamente e valorizada na legislação penal e processua penal militar (art. 39, in fine, CPM c/c art. 439 , letra "d" CPPM).

Com efeito, as causas de exclusão da ilicitude - assim consideradas excludentes, justificativas ou descriminantes - podem ser divididas em duas grandes categorias: as exemplificativas e as taxativas, abrindose neste ponto, um inconciliável debate doutrinário.

As primeiras não se esgotam nas especificações legais; como ocorre no Có digo Penal Português de 1982, o qual contempla uma cláusula âmpla de justificação, admitindo que o "facto não é criminalmente punível quando a sua ilicitude for excluída pela ordem jurídica considerada na sua totalidade" (art. $31, \mathrm{n}^{\mathrm{o}} 1$ ).

As segundas estão enumeradas no tipos penais permissivos, sujeitas ao princípio do numerus clausulus, como, aparentemente, se dá com o Código Penal e o Código Penal Militar, nos artigos 23 e 42 , respectivamente.

O Professor PAULO JOSÉ DA COSTA JÚNIOR, porém, considera o nosso sistema omisso, possibilitando o reconhecimento de causas extralegais de ilicitude (descriminantes tácitas ou não codificadas) e conclui:

"As causas de justificação não são apenas aquelas que o Código enumera, porque a juridicidade ou a antijuridicidade deve ser encarada em face de todo o direito positivo, considerado unitariamente" (in, Direito Penal Objetivo, pág. 62, 1ํoed. FV).

A propósito, é oportuno sublinhar, entre outras, estas duas referências inseridas nos Comentários ao Código Pe. nal Brasileiro:

Quanto à divulgação de segredo (arts. 153 e 154, CP), assim preleciona HUNGRIA, estreitando a sua compreensão:

"Somente exclui o crime a justa causa, entendendo-se por tal toda causa explícita ou implicitamente, direta ou indiretamente, aprovada pela ordem jurídica.

Assim, constituem justa causa: a) o consentimento do interessado (pois se trata, na espécie, de direito disponível); b) a faculdade de comunicação de crime de ação pública (art. 5o, § 3º, do Cód. de Proc. Penal); c) o dever de testemunho em juízo; d) a defesa de direito ou interesse legítimo; e) comprovação de crime ou sua autoria (art. 240, \& 1, letra f, do Cód. de Proc. Penal)". ( Vol. VI, pág. 253, Forense, $4^{\underline{a}}$ edição).

Quanto ao abandono intelectual (art. 146 CP), CÔRTES DE LACERDA adota posição mais flexível:

"O texto legal acentua que a existência do crime está subordinada à ausência de justa causa. Todo impedimento de força maior é justa causa; mas não só: dificuldades de ordem econômica da família, quando, por exemplo, a escola fica longe e a família não dispõe de meios para pagar o transporte, podem constituir justa causa. Ao juiz compete aferir quando o dolo é excluido pela justa causa". edição);

(Vol. VIII, pág. 446, Forense, 4

Enquanto a concepção de HUNGRIA pode ser considerada restritiva, aproximando-se do entendimen- to de MICHELE LONGO (in Comentários ao Código Penal Italiano, pág. 499), a posição de CÔRTES DE LACERDA é mais liberal, identificando-se com a lição do Mestre FLORIAN (apud N.Hungria, in Comentários ao Código Penal, Vol. VI, pág. 253, Nota 89, Forense, $4^{\mathrm{a}}$ ed.):

"A expressão justa causa é de se entender com maior amplitude, pois poderá haver causa justa não só na estrita previsão legal, mas também no ambito da moral, do social, da política e da religião".

Face a omissão do nosso sistema, que não impede o reconhecimento de causas extra legais de ilicitude, nos alinhamos com esta última corrente doutrinária, que alarga os horizontes da justa causa no Direito Penal.

E finalizando estas considerações, nos colocamos à disposição do plenário para debater os temas abordados e conceitos aqui emitidos. 